\title{
ENGLISH TEACHERS' PERCEPTION AND CLASSROOM PRACTICE OF BEHAVIORISM VALUES IN BALI KIDDY PRIMARY SCHOOL
}

\author{
L.G.K. Sukma ${ }^{1}$, L.P. Artini ${ }^{2}$, N.N. Padmadewi ${ }^{3}$ \\ ${ }^{123}$ English Language Education, Post Graduate Program, Universitas Pendidikan Ganesha, Singaraja \\ e-mail: luhkiranasukma@gmail.com, putu.artini@undiksha.ac.id, nym.padmadewi@undiksha.ac.id
}

This study describes teachers' perception regarding behaviourism values in teaching English for young learners in Bali Kiddy Primary School. This study involved 3 English teachers of Bali Kiddy Primary School. The objectives of this study were (1) to find out the perceptions of the English teachers in Bali Kiddy Primary School on behaviourism values in teaching English for young learners, (2) to find out how do the English teachers implement behaviorism values approach in teaching English as a foreign language in Bali Kiddy Primary School, and (3) to find out teachers' perceptions about behaviourism values related to their strategies in teaching English for young learners in the classroom. The data was collected through observation sheets, questionnaires, and interviews. The research design was mix method. The data were analysed through descriptive qualitative which supported by quantitative data. The results indicated that the stated beliefs about behaviourism values in teaching English for young learner reflect their implementation in the classroom. There were some inconsistency between the perception and implementation based on teachers' consideration on students' condition

\section{Keywords: Behaviourism value, Teachers' perceptions, Teaching English for young learners}

\section{INTRODUCTION}

The phenomenon of young learners' learning are usually different which requires the teacher to use certain ways to manage the class well. Young learners cannot be generalized in the learning process because an understanding of the material is absorbed in different ways by each of them. Young learners seem to be more enthusiastic and lively as learner (Cameron, 2001). Yet, they can also lose their focus or interest quickly and are less able to keep themselves motivated on tasks that they find difficult. Regarding to that case, it is necessary for young learner's teacher to know and understand the characteristics of young learner itself. By knowing and understanding their characteristics, it will influence many aspects in teaching English for young learner in order to create an effective teaching especially in connection with the methods used, teaching styles, lesson plan, learning materials, and the way of getting their attention.

Young learner characteristics differ from adult learners in learning. There are some characteristics of young learner that should be known by teacher in order to create good atmosphere in classroom. Sadler (1974) argues that children learn from concrete to abstract and naturally curious as well as develop quickly as individual. It is in line with Sadler (2006) who confirms that young learners have great curiosity to try new things and explore concrete to abstract things. Therefore, teaching abstract concepts should be avoided by teacher. It is better to focus on concrete items that young learner understand and relate to. The use of teaching media is recommended to deliver the material which can make student easily to understand. Another characteristics of children is explained by Cameron (2001) who states that young learners actively construct meaning from their experiences. It is similar with Harmer's statement (2001) who says that young learners are able to understand not only from explanation but also from what they see and hear. In this case, young learner can learn from their real experience and relate it to the material on the process of learning. The teacher has to conduct the effective teaching for young learners which should be integrated to the habit as well as characteristics of 
young learners. The fun activities in learning process could make young learner easier to understand the material. This is the duty of teacher to provide the material and media that are appropriate for young learners need. In this case, the improvement which is made by the teachers in their teaching must affect the enhancement of the students' learning achievement.

Considering on those characteristics, teacher should have special sensitivity and expertise to understand young learners' characteristics so that they will be able to make them enjoy the learning process to achieve learning goals. Yet, in the form of human resource, nowadays there are many schools that employ teachers who are graduated from English language education where they are expected to teach secondary school and they are not specialized in children pedagogy. This can be a problem for the teacher, especially for those who are graduated from English language education when teaching children to adjust to their characteristics because of the lack of knowledge about young learner. However, this is not a big problem because there are several approaches that can be used as a reference for teaching young learner, such as natural values, constructivism values, behavioristic values, children literature and learning style. Yet among those values, behavioristic approach will be deeply explained in this study since this values is really effective to make the students involved in the process of learning itself and shape students' good behavior. Behavioristic approach is narrowed down into values that can be transferred into activities inside classroom since it cannot be applied directly into language learning. Behaviorism values comes from the theory of behaviorism. This behaviorism trend was? transformed into pedagogical approach which is called behavioristic approach. Behavioristic approach has some components which is considered as behaviorism values.

Perception is a response or opinion that is a process of the individual to receive or know about something through the senses. A number of factors may play a role in shaping teachers perceptions of classroom behavioristic. One of the most influential factors is the teachers' orientation to behavioristic as values. The process of receiving stimulus between an individual with other individuals is different according to internal factor and external factor of each individual. Differences in understanding resulted in differences in perceptions between individuals with one another. Teacher's perception is the response of a professional educator about what is experienced in educating, teaching, guiding, directing, training, assessing and evaluating children of the aged child in the educational pathway that is influenced by the beliefs and feelings of the educator. This difference in understanding will cause different judgments of each teacher.

The different of the teachers' understanding influence the way of the behavioristic implementation (Widiastuti, 2017). The different way of behavioristic can lead to different perceptions which are very subjective. Different perceptions may affect the teacher's behavior on the judgments they made. Teacher' perceptions can be divided into two categories namely positive perceptions and negative perceptions. Positive or good teacher perception will become a good foundation in responding to all matters relating to the behavioristic process, including the readiness of behavioristic implementation. Meanwhile, a negative perception of the behavioristic will become a barrier of the conduction of rules relating to the process Behavioristic in 2013 curriculum. Behavioristic of the students' learning outcomes includes the attitudes competence, knowledge, and a balance of skills, so it can be used to determine the relative positions of each learner to against the standards that have been applied. Learning Behavioristic is inseparable from the role of educators. Teachers have freedom in determining the behavioristic techniques to be used. From preliminary interviews and observations conducted by the authors in Bali Kiddy School, there are various questions? related to the behavioristic values. Are all teachers familiar with the behavioristic values? Have teachers implemented the behavioristic in their teaching and learning process? What do Indonesian teachers think about behavioristic values? Based on the background that has been described above, the research focus of this research is about behavioral perspective of teachers in Bali Kiddy Primary School. Bali Kiddy School was chosen because this school is one of private schools which provides an integrated curriculum both 
national curriculum and international curriculum that make this school have different method of teaching. The various background of the teacher was also becoming a consideration to choose this school as an object for the research. Based on this general problem, some problems relating to teachers' perceptions of authentic judgment may be formulated. The result of this study is to find out the perception of teacher in implementing behavioristic values in teaching English for young learner in Bali Kiddy School. In behavioristic learning theory, people believe that behavior will determine the learning process of an individual. According to Budiman (2017), behavioristic emphasizes on human behavior as a result of the interaction between stimulus and response. This theory proposes that if a person make a change of behavior, reflecting that he has learn something. Here, the role of stimulus are very significant in determining students' behavior in learning process. Students will show a good behavior only if the teacher give an appropriate stimulus to their children.

Behaviorism theory is crucial in foreign language learning. The influence of this theory can be seen in the implementation of teaching learning process. Skinner in Roche (2007) defines that behaviorism values refer to the custom of groups, and the main effect of a culture is to bring the individual under the control of remote consequences of behavior.

\section{METHOD}

The research design of this study was mixed method design. Mixed method research involved the use of both qualitative and quantitative method in single study or a series of studies to understand a research problem (Creswell, 2012). The use of both methods provided more complete understanding of research problems. Moreover, by combining qualitative and quantitative research values can expand and strengthen a study's conclusions (Schoonenboom, $\mathrm{J} \&$ Johnson, R.B, 2017). The type of mixed method used in this study was embedded design analysis. In this study, the rationale of using the embedded design analysis was to investigate the teachers' perceptions and the implementation of behaviorism values in teaching English for young learners in Bali Kiddy Primary School. The data was collected in both qualitative and quantitative research based on the research questions of this study and then all of data described qualitatively in the findings (qualitative dominant). In conducting this study, the researcher followed seven phases values which were proposed by Creswell (2012). In this phase, the researcher started in conducting mix method study and checking whether this method was feasible for this present study since this study focused on the perception, the implementation, and the relation which used two types of research designs that were qualitative and quantitative. However, this study presented the results of findings by using quantitative research.

After determining the mixed methods study as being the method used, then, the researcher began to find out the rationale in conducting a mix methods study. Here, the researcher tried to relate the three research questions in this study to be a basis in conducting a mixed methods study.

In this phase, the researcher began to find out and made a draft of data collection strategy and type of design would be used in this present study.

In this step, the researcher began to develop the instruments to answer all of the research questions. Here, the researcher started to develop three instruments, such as: observation sheets, interview guides, and questionnaires in which would be used to collect the qualitative and quantitative data. Before conducting all of the instruments, the researcher created blue prints of questionnaire and observation sheet based on the theories which were suitable in answering the research questions.

After developing the instruments, the researcher started to administer to a sample of this study. First, conducting observation in the class of three teachers, spread the questionnaires at the end of the observation, and followed up by doing interview with each teacher. In this step, the researcher started to analyse the data by using the data analysis theory used in this study 
both qualitative and quantitative analysis. Here, the quantitative only used to support the main data that was qualitative data. After all of the result of the data were collected, the next step was wrote the report of the data based on the findings descriptively.

\section{FINDINGS AND DISCUSSIONS}

Perception is a response or opinion that is a process of the individual to receive or know about something through the senses. A number of factors may play a role in shaping teachers perceptions of classroom behaviors. One of the most influential factors is the teachers' orientation to behavioristic as avalues. The process of receiving stimulus between an individual and other individuals is different according to internal factor and external factor of each individual. Differences in understanding resulted in differences in perceptions between individuals with one another. Teacher's perception is the response of a professional educator about what is experienced in educating, teaching, guiding, directing, training, assessing and evaluating children of the aged child in the educational pathway that is influenced by the beliefs and feelings of the educator. This difference in understanding will cause different judgments of each teacher.

The qualification were very strong for all indicators which indicates that all of teacher in Bali Kiddy have very strong perception about behaviorism values.

Starting from the first value about the possibility of organism to display certain behavior through reinforcement, all of the teachers has very strong perception about this value. All of them gave 5 which indicated that all of teachers was very strong agree to use reinforcement to appreciate students' good behavior as well as their big effort in participating towards learning process in the classroom.

All teachers also have very strong perception in the second value that is an organism display behavior to a stimulus. These three teachers were very strong agree that stimulus is an essential thing to be given in order to make the students react or participate in the learning process.

In the third value that is about conditioning which is reinforced at least from time to time in order to continue after it is established. All of the teachers have strong perception in this indicator. These teachers were strongly agree that conditioning has to be given repeatedly after it is established.

In the form of giving rewards these three teachers have very strong perception about this value. All of the teachers were strongly believe that providing various rewards based on students' ability was important in order to encourage the students during the lesson. Besides having a very strong perception about giving various rewards to the students based on their behavior, the teachers also have a strong perception about giving pleasant and unpleasant punishment for the students who did misbehavior in the classroom. The average score were 4.3 which belongs to very strong perception.

The last value was giving reaction to a new stimulus as a result of associating a different stimulus with the related stimulus. All of the teachers have very strong perception on this value. The average score was 4.5 which belongs to very strong perception. They all believe that giving reaction to a new stimulus must be given as a result of associating a different stimulus with the related stimulus.

Thus, from the summary given, it can be concluded that all of the teacher have very strong perception about behaviorism values to build students' good behavior in the classroom.

The different of the teachers' understanding influence the way of the behavioristic implementation (Widiastuti, 2017). The different way of behavioristic can lead to different perceptions which are very subjective. Different perceptions may affect the teacher's behavior on the judgments they made. Teacher' perceptions can be divided into two categories namely positive perceptions and negative perceptions. Positive or good teacher perception will become 
a good foundation in responding to all matters relating to the behavioristic process, including the readiness of behavioristic implementation.

Meanwhile, a negative perception of the behavioristic will become a barrier of the conduction of rules relating to the process Behavioristic in 2013 curriculum. Behavioristic of the students' learning outcomes includes the attitudes competence, knowledge, and a balance of skills, so it can be used to determine the relative positions of each learner against the standards that have been applied. Learning Behavioristic is inseparable from the role of educators. Teachers have freedom in determining the behavioristic techniques to be used. From preliminary interviews and observations conducted by the authors in Bali Kiddy School, there are various responses related to the behavioristic values. Based on the questionnaire given to the teacher, all of teacher have a very good understanding about behaviorism values. In the form of implementation, the subject of this research, that is, the three teachers of Bali Kiddy Primary School were observed during their teaching process in the school. The results were all of the teachers implemented almost all of the values that have been divided into several indicators. The highest frequencies goes to the implementation of giving positive reinforcement to the students. All of the teachers always appreciate every single effort that the students show in the classroom.

Their method of teaching is also influenced by the teaching experience as well as their education background. For instance, teacher 1 has already been teaching in Bali Kiddy since 2013. From her teaching experience, she knew how to handle various type of students and she could easily find new method of teaching if she thought that it did not work for the students. The other example was teacher 2, she was graduated from Tasmanaia University Australia for her postgraduate. T2 used a lot of kind of rewards compared to the other teachers. After following up this thing in the interview, T2 said that she learnt how to make various rewards and how to use an appropriate rewards in the university in Australia that make her know how to make it and use it as well.

Thus the teaching experience and also educational background have strong influence to the method of teaching in the classroom. It also influences the perception of the teachers. If the teacher often joined seminar or training, they would have wide thought about implementing behaviorism values in the classroom. They know the importance of behaviorism values to be applied in the classroom.

Teachers in Bali Kiddy School mostly join seminar or training that is held whether by the school or government institution. Therefore, these three teachers have a very good understanding about behaviorism values. It was also in line with the implementation. Almost all of the value in behaviorism values were implemented very well and it created balanced result with the perception. However, there is a value that got very low score in the form of implementation. That value is about giving reaction to a new stimulus as a result of associating a different stimulus with the related stimulus. It was rare for the teacher to give stimulus since most of the students in Bali Kiddy were very active. It made the teachers did not need to give stimulus to the students.

In the form of implementation all of the teachers have already applied the value of behaviorism values with the frequency for three meetings observation. Starting from the first value about the possibility of organism to display certain behavior through reinforcement which got the highest number of scores from all of the values. T1 implemented this value in the classroom $24.7 \%$ from the total activity of this value. T2 implemented $24.7 \%$ which got the highest scores from the other teachers and T3 implemented $25.8 \%$ of this value. The average for the first value was $33.2 \%$.

All teachers also implemented the second value that is an organism display behavior to a stimulus as much as $10.8 \%$ of average from the total activities of this value. T1 implemented the activities of this value as much as $14.8 \%$, T2 implemented it as much as $18 \%$ which got the highest score in this value, and T3 implemented it as much as 7\%. 
In the third value that is about conditioning which is reinforced at least from time to time in order to continue after it is established. The total average of this value was $33.2 \%$ from all of the activities in this value. T1 implemented $15.8 \%$ activities in this value, T2 implemented $12.3 \%$ and T3 implemented $15.2 \%$ activities in this value

The fourth value is conditioning that is reinforced at least from time to time in order to continue after it is established. For this value the average was 12.6 or $10.5 \%$ in percentage for the whole activities from the value itself.In the form of giving stimulus to build a good behavior, the total average from three meetings was 25.3 or $21.3 \%$ in percentage.

The last value was giving reaction to a new stimulus as a result of associating a different stimulus with the related stimulus. All of the teachers have applied certain activity for this value with the average was 7.3 or $6.1 \%$ from three meetings observation which got the lowest score rather than other value.

Thus, from the summary given, it can be concluded that all of the teacher have already implemented the activities which included in every value with almost the same frequencies of implementation in the classroom.

Starting from the first value that is the possibility of an organism to display certain behavior through reienforcement, the result was very strong in the form of perception as well as very high frequency in the implementation. Both teachers' perception and implementation were balanced.

The second value that is organism display behavior to a stimulus, the result was very strong in perception. Yet in the form of implementation, the result were low frequency with the score 13.3

The result of the third value that is conditioning is reinforced at least from time to time in order to continue after it is established showed that both of teachers' perception and its implementation were different. The perception of all teachers showed that they have a very strong perception about this value. Yet. The implementation of this value were low

Balanced result were also gotten from the fourth value that is different applications of rewarding an organism depending on time and behavior. The perception of teachers on this value were very strong. It was the same with the implementation that categorized as very high implementation in the classroom.

The fifth value was give unpleasant stimulus and pleasant stimulus as punishment. The result on this value was very strong on teachers' perception as well as very high in the form of implementation in the classroom. It made balance result between the perception and implementation since the implementation also showed very high frequency used in the classroom

However, in the last value that is about giving reaction to a new stimulus as a result of associating a different stimulus with the related stimulus. The result was not balanced. In the form of perception, all of the teacher have a very strong perception on it. Yet, in the form of implementation, the results was very low which indicates that all of the teachers did not really applied an indicator included in this value.

The finding indicates that the research was mismatched, there were inconsistency between what the teacher already knew and what the teacher already practiced. Yet, there were some reasons behind that case. For instance the situation of the students and the classroom.

Thus, the teacher in Bali Kiddy Primary School had a very strong perception on Behaviorism values. They understand the importance of implementing this value. These perceptions guide them to implement these values to teach the students in the classroom. Yet, there were some inconsistencies between the perception and the implementation because of the situation in the classroom and teachers' consideration based on students' condition and classroom condition. Besides, teachers in Bali Kiddy do not only work as teacher in the classroom. They were also involved in others activities or event held by the school. Therefore, sometimes the teacher needs to do an extra job that makes them have to modify or look for alternative to give reinforcement to their students. Yet, it was managed really well by teachers. 
Based on the observation, the students easily understood the learning material and most of the time they enjoyed the class activity.

\section{REFERENCES}

Cameron, Lyne. (2001). Teaching Languages to Young Learners. New York: Cambridge University Press.

Creswell, John W. (2007). Educational Research: Planning, Conducting, and Evaluating Quantitative and Qualitative Research (Third Edition). Harlow: Pearson Education.

Coplan, F., \& Garton, S. (2014). Key themes and future directions inteaching English to young learners: Introduction to the Special Issue. ELT Journal, 68(3), 223-229.

Dembo, M. H., \& Seli, H. (2012).Motivation and Learning Strategies for College Success: $A$ Focus on Self-Regulated Learning. United Kingdom: Erlbaum.

Demirezen, M. (1988). Behaviour theory and language learning. Hacettepe Vniversitesi Eğitim Fakültesi Dergisi, 3, 135-140.

England, E., \& Finney, A. (2011).Interactive Media-What's that? Who's involved. United Kingdom: ATSF White Paper.

Fan, J., Feng, H., \& Yang, H. (2013). The relationship of learning motivation and achievement in efl: gender as an intermediated variable.Educational Research Internatioal, 2(2),50-58.

Gawi, E. M. K. (2012). The effect of age factor on learning English: A case study of learning English in Saudi schools, Saudi Arabia. English Language Teaching, 5(1), 127-139.

Ghavifekr, S., Razak, A. Z. A., Ghani, M. F. A., Ran, N. Y., Meixi, Y., \& Tengyue, Z. (2014). ICT Integration In Education: Incorporation for Teaching \& Learning Improvement. The Malaysian Online Journal of Educational Technology, 2(2), 24-44.

Harmer, J. (2001). The Practice of English Language Teaching. Edinburgh: Longman

Huyen, N. T., \& Nga, K. T. (2003). Learning vocabulary through games: The effectiveness of learning vocabulary through games. The Asian EFL Journal, 5(4).

Khalid, A.\& Azeem, M. (2014). Constructivist Vs Traditional: Effective Instructional Approach in Teacher Education. International Journal of Humanities and Social Science, 2(5), 170-176.

Kurniasih, E. (2011). Teaching the four language skills in primary EFL classroom: some considerations. Journal of English Teaching, 1(1), 70-81.

Leow, F. T., \& Neo, M. (2014). Interactive multimedia learning: innovating classroom education in a malaysian university. TOJET: The Turkish Online Journal of Educational Technology, 13, 99-110.

Li, Y. W. (2016). Transforming Conventional Teaching Classroom to Learner-Centred Teaching Classroom UsingMultimedia-Mediated Learning Module. International Journal of Information and Education Technology, 6(2), 105-112.

Linse, C. (2005). Practical English Language Teaching: Young Learner. New York: McGraw Hill.

Mart, C. T. (2012). Encouraging young learners to learn English through stories. English Language Teaching, 5(5), 101-106.

McKay, P. (2006). Assessing young language learners.Cambridge: Cambridge University Press. 
Mauludiyyah, R. (2014). The Effectiveness of Songs, Pictures, and Combination of Songs and Picture in The Teaching Learning Process of Mastering. Jurnal Penelitian, Pendidikan dan Pembelajaran, 3(15), 398-401.

Olakulehin, F. K. (2007).Information and communication technologies in teacher training and professional development in Nigeria. Turkish Journal of Distance Education TODJE, 8(1), 133-142.

Patton, M. Q. (2002). Qualitative evaluation and research methods (3rd ed.). Thousand Oaks, CA: Sage Publications, Inc.Pinter, A. (2006). Teaching Young Language Learners. China: Oxford University Press.

Ramendra, D. P. \&Ratminingsih, N. M. (2007). Pemanfaatan Audio Visual Aids (AVA) dalam proses belajar mengajar mata pelajaran Bahasa Inggris di sekolah dasar. Jurnal Penelitian dan Pengembangan Pendidikan, 1(2), 78-95

Ratminingsih, N. M. (2012). Teaching techniques, types of personality, and English listening skill. Jurnal Ilmu Pendidikan, 18(1), 23-29.

Scott, W. A., \& Ytreberg, L. H. (1990). Teaching English to Children. New York: Longman.

Serostanova, N. (2014). Integrating informationand communication technologiesin the process of foreign language teaching and learning. Journal of EducationCulture and Society, 1), 187197.

Şenel, M., \& Akman, D. B. (2016).Fun teaching ! Fun Tech-ing ! Interactive Educational games for Young Learners. Participatory Educational Research, 1(2), 12-21.

Sugiyono (2007).Metode Penelitian Pendidikan: Pendekatan Kuantitatif, Kualitatif, dan R\&D. Bandung: Alfabeta Bandung.

Wang, F. (2008). Motivation and English Achievement: An Exploratory and Confirmatory Factor Analysisof a New Measure for Chinese Students of English Learning. North American Journal of Psychology, 10(3), 634-646.

Yolageldili, G., \& Arikan, A. (2011). Effectiveness of using games in teaching grammar to young learners. Elementary Education Online, 10(1), 219-229.

Yuliana (2003). Teaching English to Young Learners through Songs. Journal Directory, Collection of Kata, 5(1), 62-66. 